\title{
Article \\ Complementary Feeding Practices and Parental Pressure to Eat among Spanish Infants and Toddlers: A Cross-Sectional Study
}

\author{
Michelle Klerks ${ }^{1,2}{ }^{\mathbb{D}}$, Sergio Roman $^{3}$, Maria Jose Bernal ${ }^{1,2} \mathbb{D}$, Juan Francisco Haro-Vicente ${ }^{1,2}$ (D) \\ and Luis Manuel Sanchez-Siles 1,2,*(D) \\ 1 Hero Group, Research and Nutrition Department, 30820 Murcia, Spain; michelle.klerks@hero.es (M.K.); \\ mjose.bernal@hero.es (M.J.B.); jfrancisco.haro@hero.es (J.F.H.-V.) \\ 2 Hero Group, Institute for Research and Nutrition, 5600 Lenzburg, Switzerland \\ 3 Marketing Department, Facultad de Economía y Empresa, University of Murcia, 30100 Murcia, Spain; \\ sroman@um.es \\ * Correspondence: luisma.sanchez@hero.es
}

check for updates

Citation: Klerks, M.; Roman, S.; Bernal, M.J.; Haro-Vicente, J.F.; Sanchez-Siles, L.M. Complementary Feeding Practices and Parental Pressure to Eat among Spanish Infants and Toddlers: A

Cross-Sectional Study. Int. J. Environ. Res. Public Health 2021, 18, 1982. https://doi.org/10.3390/ijerph18041982

Academic Editors: Nikki

Ann Boswell, Rebecca Byrne,

Ruth Newby, Paulina Nowicka and Emma Haycraft

Received: 19 January 2021

Accepted: 15 February 2021

Published: 18 February 2021

Publisher's Note: MDPI stays neutral with regard to jurisdictional claims in published maps and institutional affiliations.

Copyright: (c) 2021 by the authors. Licensee MDPI, Basel, Switzerland. This article is an open access article distributed under the terms and conditions of the Creative Commons Attribution (CC BY) license (https:// creativecommons.org/licenses/by/ $4.0 /)$

\begin{abstract}
The introduction of complementary foods is a crucial stage in the development and determination of infants' health status in both the short and longer-term. This study describes complementary feeding practices among infants and toddlers in Spain. Also, relationships among sample characteristics (both parents and their child), feeding practices (timing, type of complementary food), and parental pressure to eat were explored. Cognitive interviewing with 18 parents was used to refine the survey questions. Responses from a national random sample of 630 parents, who were responsible for feeding their infants and toddlers aged 3-18 months, were obtained. Solids, often cereals and/or fruits first, were introduced at a median age of five months. Fish and eggs were introduced around the age of nine and ten months. Almost all children were fed with home-prepared foods at least once per week (93\%), and in 36\% of the cases, salt was added. Interestingly, higher levels of parental pressure to eat were found in female infants, younger parents, parents with a full-time job, the southern regions of Spain, and in infants who were not fed with home-prepared foods. Our insights underline the importance of clear feeding recommendations that can support health care professionals in promoting effective strategies to improve parental feeding practices.
\end{abstract}

Keywords: complementary feeding practices; home-prepared food; parental pressure to eat; health; Spain

\section{Introduction}

Early childhood overweight and obesity represent a major health problem, particularly in developed countries [1,2], and Spain is no exception as evidenced in many studies over the years [3-7]. The current study provides new insights about complementary feeding practices of infants and toddlers in Spain. The introduction of complementary foods is a crucial stage in the development and determination of infants' health status in both the short and longer-term [8-11]. Furthermore, the order of introduction, variety, and repeated exposure to complementary foods are related to the development of food preferences and eating habits later in life [12-17]. As a result, it is not surprising that: "the way in which a child is introduced to complementary foods may have effects on the individual's entire life" [11] (p. 1).

Despite the importance of complementary feeding, there seem to be many perspectives regarding its "adequate" implementation. The World Health Organization (WHO) recommends exclusively breastfeeding infants up to six months of age and introducing complementary foods thereafter [18]. The European Food and Safety Authority (EFSA) and the European Society for Paediatric Gastroenterology, Hepatology and Nutrition (ESPGHAN) support the desirable goal to exclusively breastfeed until six months of age, as recommended by the $\mathrm{WHO}$, however they elaborate on the possibilities to introduce complementary foods between the age of four and six months [19-21]. The EFSA recently 
concluded that no precise age for the start of complementary feeding can be determined, as this heavily depends on the infant's characteristics and development [21]. In particular, they highlight that "Most infants do not need complementary foods for nutritional reasons up to around six months of age, with the exception of some infants at risk of iron depletion" (p. 5) and "that an infant might be developmentally ready for complementary foods before six months does not imply that this is necessary or desirable" (p. 5) [21]. As WHO considers infant formula as a complementary food, their recommendations are not directly comparable with those from EFSA and ESPGHAN, which exclude infant formula from complementary food [18-21]. Therefore, it is not surprising that a recent study [22] showed that in 31 of 38 European countries (82\%) the introduction of complementary foods was recommended before six months. It was found that age recommendations differed in some countries depending on whether the infant is breastfed or formula-fed. In some countries (e.g., Germany and the UK) parents do not always wait for the introduction of foods until their infant reaches the recommended age [23-25]. In fact, consumption of solids before the recommended age can be found in any region globally, but the highest rates are found in Latin America and the Caribbean, and East Asia and the Pacific. In these regions, approximately $15 \%$ of infants are fed solids already when they are between two and three months old [26]. Accordingly, "the debate on the optimal age of solid food introduction is still open" [11] (p. 2) and "should be further investigated" [11] (p. 12).

On a related issue, there is no consensus regarding the concrete order in which foods should be introduced [27], except for the recognized importance to complement the nutritional requirements of iron at six months of age [28]. Recommendations also seem to change over time. For instance, in Spain, it was recommended not to start with cereals with gluten, fish, and eggs until the age of eight to nine months, and legumes until 12 months [29], while currently, the recommendations are to introduce these foods, along with fruit, vegetables, meat, chicken and olive oil somewhere between 6-12 months [30]. More importantly, a gradual increase in variety and consistency of foods is regarded as essential from the beginning of complementary feeding [30,31]. Overall, differences in local culture seem to play a key role in shaping complementary feeding practices.

Most of what we know until now about what and when infants and toddlers are fed up to two years of age, follows from observational studies administered in African developing countries [32-36], other non-Western countries like Vietnam and the United Arab Emirates [37-39], and developed countries such as the US and Canada [40,41]. Within Europe, infant feeding practices have been extensively investigated by observational studies in Scandinavian countries [42-45], the UK, Italy, Switzerland, Germany, the Netherlands, and France [23,25,46-55]. On the contrary, research about feeding practices in Spain has been mostly focused on children above two years of age and adolescents (e.g., [56-58]). Only a few studies have included infants and toddlers below 18 months, but they were focused on nutrient intake and adequacy [59-63].

Complementary feeding practices also involve specific behaviors parents apply to control how much their children eat. These behaviors relate to a parental feeding style (e.g., [64]). The pressure to eat, restriction of food, and the use of food as a reward are examples of them [65]. In this study, we are particularly interested in parental pressure to eat. Parental pressure to eat, in which parents do not respond to the child's satiety signals and encourage their food intake [66], may cause children to be unable to regulate their own food intake [67]. Importantly, the pressure to eat "may have the unintended consequence of disrupting the development of intuitive and adaptive eating" [68] (p. 61) and has been associated with a tendency to overeat [69] and greater risk for overweight [70].

In summary, despite the general consensus about the pervasive importance of complementary feeding, there is an open debate in the academic community regarding when, what, and how much infants should eat in the complementary feeding stage. This study aims to provide a comprehensive description of feeding practices among Spanish infants and toddlers aged 3-18 months, including the timing of introduction, types of complementary food, and home-prepared feeding habits. In addition, we explore potential associations 
among parental and infant characteristics, feeding practices, and parental pressure to eat. A better understanding of these practices and their relationships can be used for further development of different approaches towards healthy complementary feeding in Spain and other similar developed countries.

\section{Materials and Methods}

\subsection{Study Design and Participants}

The current study analyzed data from a larger research project [71,72] about infants' and toddlers' eating behaviors, their nutritional status, and parents' use of formula milk and complementary infant foods (e.g., cereals, baby jars, home-prepared foods). Data were collected in Autumn 2014. Different sizes of parent samples were used. Participants consisted of parents who: (1) had at least one child aged 3-18 months, (2) had primary responsibility for their infant feeding, and (3) their child did not have severe food allergies or chronic medical problems affecting their food intake. Ethical approval was obtained from the Research Ethical Committee of the University of Murcia.

Cross-sectional data were collected through an online consumer survey. A research firm collected the data and randomly selected a sample of Spanish parents whose infants and toddlers (aged 3-18 months) were representative for gender and Spanish Region from their online national panel. The initial sample consisted of 749 respondents. 34 cases were eliminated because of incomplete or inconsistent responses. 85 cases were not included in the data analyses of this study because parents did not feed their infants with complementary foods. The final sample consisted of 630 respondents.

\subsection{Questionnaire}

An initial version of the questionnaire was developed by the authors based on a literature review $[41,51,73-76]$ along with feedback obtained from experts in nutrition and market research. The questionnaire was then tested among 18 parents using cognitive interviewing techniques. Most of them were female (88.9\%), with a mean age of 34.3 years. Cognitive interviews require respondents to "think-aloud" or verbalize their thought process while completing the survey [77] (p. 287). This technique has been extensively used to test food and nutrition-related questionnaires (e.g., [75,78]).

The questionnaire was then distributed to a final pilot sample of 197 parents of children aged 3-18 months in Madrid, Barcelona, Sevilla, and Murcia. Trained interviewers randomly approached parents who were with their infant(s) in parks or at the entrance of the kindergarten. Most of the respondents were female (89.3\%) and had a college degree $(58.9 \%)$. Item means, frequencies, and alpha coefficients were calculated.

\subsubsection{Demographic Characteristics}

Children demographic variables included age, gender, birth weight, position between brothers/sisters, and daycare attendance. Infant weight-for-age percentile was calculated using the WHO guidelines [79]. Parents demographics included age, gender, residence (both region and size of city), education, job intensity, monthly income, and marital status.

\subsubsection{Complementary Feeding Practices}

Parents were asked to indicate whether they were feeding their child with a selection of food categories (cereals, fruits, vegetables, yogurt, meat, cheese, fish, eggs, and legumes) and the age of the child at which each of these foods categories were introduced (timing). Intake frequency per food category per week was also asked on a 5-point interval (from "every day" to "rarely").

As for home-prepared feeding practices, parents answered who prepared it (mainly the parent, both the parent and someone else or mainly someone else), if salt was added while cooking it, type of food (puréed fruit, puréed vegetables, menu with meat and menu with fish) and intake frequency per week. 


\subsubsection{Parental Pressure to Eat}

A three-item 5-point Likert scale (from $1=$ "strongly disagree" to $5=$ "strongly agree"), adapted from Birch et al. (2001) [74], was used to measure parental pressure to eat. One item of the original scale was found redundant as a result of the cognitive interviews and thus it was eliminated.

\subsection{Data Analysis}

A descriptive analysis was carried out to obtain demographic characteristics, the timing of complementary feeding, intake frequencies of different food categories, and home-prepared feeding practices. Before analyses of quantitative data, normality was checked by the Kolmogorov-Smirnov test. Non-parametric data were presented in the median and interquartile range (Q3-Q1), while normal data as mean \pm standard deviation (SD). Categorical variables are reported as percentages. The reliability of the multi-item scale was tested by calculating the composite reliability (CR). Research recommends cut-off values of 0.60 [80]. Two-tailed Pearson correlations and one-way analyses of variance (ANOVA) were carried out. Statistical analyses of data were performed using the Statistical Package for the Social Sciences (IBM SPSS Statistics for Windows, Version 25.0; Armonk, NY, USA; IBM Corp).

\section{Results}

\subsection{Demographic Characteristics}

The children's and parents' characteristics $(n=630)$ are described in Table 1. Slightly more than half of the children (54.6\%) were toddlers between 12 and 18 months old, $51.3 \%$ of the total sample were boys and $38.9 \%$ attended the daycare. Parents, of which $79.5 \%$ were mothers, were on average $34.6 \pm 4.2$ years old. Most of the investigated families lived in a medium or big city (63.2\%), primarily in the center of Spain (168 families, $26.7 \%$ ). About three-quarters of the parents had a university degree and a quarter did not have a job. Almost all parents were married or lived together with a partner (94.4\%).

Table 1. Demographic characteristics, $n=630$.

\begin{tabular}{ccc}
\hline & $n$ or Mean \pm SD & Percentage (\%) \\
\hline Characteristics of infants and toddlers & & \\
\hline Age (months) & $11.8 \pm 3.6$ & 8.9 \\
$3-6$ months & 56 & 36.5 \\
$7-11$ months & 230 & 54.6 \\
$12-18$ months & 344 & \\
\hline Gender & & 51.3 \\
Boy & 323 & 48.7 \\
Girl & 307 & \\
\hline Birth weight (g) & $3222 \pm 493$ & 32.9 \\
First & 39 & 5.1 \\
Second & 207 & 0.8 \\
Third & 32 & 55.1 \\
Fourth & 5 & 38.9 \\
Position between brothers/sisters & 347 & 61.1 \\
\hline Daycare attendance & & \\
Yes & 245 & \\
No & 385 & \\
\hline
\end{tabular}


Table 1. Cont.

\begin{tabular}{|c|c|c|}
\hline & $n$ or Mean \pm SD & Percentage $(\%)$ \\
\hline \multicolumn{3}{|c|}{ More than three days a week lunch at daycare } \\
\hline Yes & 172 & 27.3 \\
\hline No & 73 & 11.6 \\
\hline \multicolumn{3}{|l|}{ Characteristics of parents } \\
\hline Age (years) & $34.6 \pm 4.2$ & \\
\hline \multicolumn{3}{|l|}{ Gender } \\
\hline Female & 501 & 79.5 \\
\hline Male & 129 & 20.5 \\
\hline \multicolumn{3}{|l|}{ Region } \\
\hline North-East & 121 & 19.2 \\
\hline East & 90 & 14.3 \\
\hline South & 124 & 19.7 \\
\hline Center & 168 & 26.7 \\
\hline North-West & 63 & 10.0 \\
\hline North & 55 & 8.7 \\
\hline Canary Islands & 9 & 1.4 \\
\hline \multicolumn{3}{|l|}{ City size } \\
\hline Medium/big city & 398 & 63.2 \\
\hline Small city/village/countryside & 232 & 36.8 \\
\hline \multicolumn{3}{|l|}{ Education } \\
\hline Primary school & 15 & 2.4 \\
\hline Secondary school & 146 & 23.2 \\
\hline University bachelor/master/PhD & 469 & 74.4 \\
\hline \multicolumn{3}{|l|}{ Job intensity } \\
\hline Full-time & 378 & 60.0 \\
\hline Part-time/per hours & 107 & 17.0 \\
\hline Unknown/not working & 145 & 23.0 \\
\hline \multicolumn{3}{|l|}{ Total monthly income $(€)$} \\
\hline$<1000$ & 43 & 6.9 \\
\hline$>1000$ & 491 & 77.9 \\
\hline Do not know / no answer & 96 & 15.2 \\
\hline \multicolumn{3}{|l|}{ Marital status } \\
\hline Divorced/single & 35 & 5.6 \\
\hline Married/living with a partner & 595 & 94.4 \\
\hline
\end{tabular}

\subsection{Complementary Feeding Practices}

\subsubsection{Timing of Introduction}

The median age at which complementary foods were introduced was five months, with the first quartile at four months and the third quartile at six months. Of the total sample, 50 infants $(8 \%)$ were introduced to solids at or during the age of three months. The majority of the infants that were introduced at or during the third month were offered cereals as their first complementary foods (39 infants, $78 \%$ ). During the fourth and fifth month, 350 infants were introduced to solids (56\%), 162 infants at six months $(26 \%)$, and 68 $(11 \%)$ beyond six months.

Each food category was introduced at different age stages (Figure 1). Cereals (78\%) and fruits $(70 \%)$ were for most of the infants the first introduced solid foods at a median age of five months, followed by vegetables (32\%) at a median age of six months, and yogurt $(20 \%)$ and meat $(15 \%)$ both at a median age of seven months. Fish, cheese, legumes, and 
eggs were the least chosen first solid foods. Fish was introduced at a median age of nine months, and cheese, eggs, and legumes at 9.5, 10, and 11 months, respectively (Figure 1).

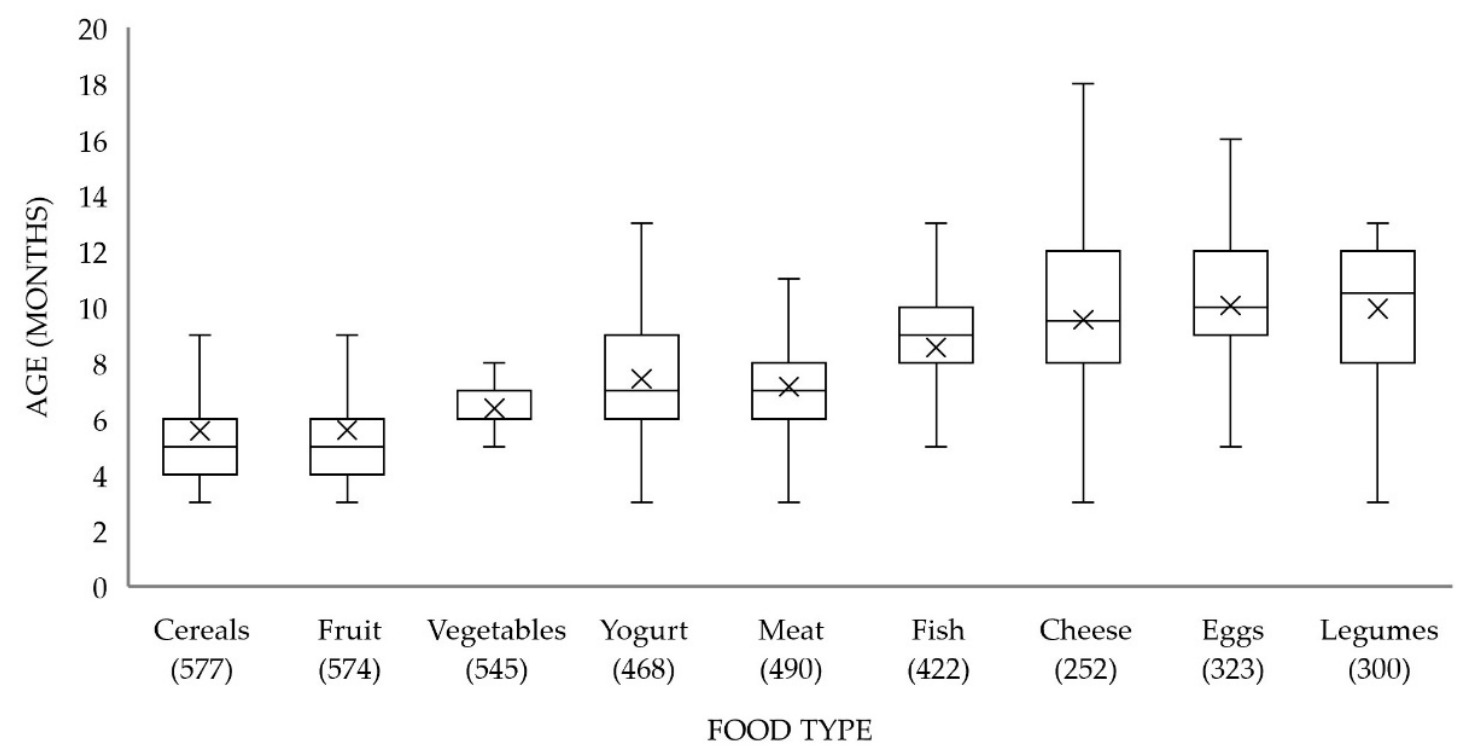

Figure 1. The age of introduction of each food category into the Spanish infants' diets. The line in the boxplots represents the median and the cross represents the mean. The number between parentheses is the number of infants from the total sample that had already been introduced to the corresponding food category.

\subsubsection{Frequency of Intake}

The frequency of intake in which each food category was introduced per age group is depicted in Table 2. Almost half of the infants were fed with cereals every day in the age groups 7-11 months (46\%) and 12-18 months (49\%). In the age range of 3-6 months, cereals were given for $27 \%$ every day. Fruits and vegetables were given five to seven times a week around $90 \%$ of the cases in all age groups. Yogurt was more often given in the older age ranges. Between $7-11$ and $12-18$ months, yogurt was provided daily to $43 \%$ and $59 \%$ of the infants that received yogurt, respectively. Meat was mostly given three to four days a week between $7-11$ months (36\%) and between 12-18 months (45\%). Fish was generally given three to four days a week: for around $45 \%$ in the age ranges 7-11 and 12-18 months. Eggs and legumes were not common to provide to infants (3-11 months), they were more likely to be given to toddlers (12-18 months). In particular, in this age group, both eggs $(71 \%)$ and legumes $(56 \%)$ were for the majority given one or two days a week (Table 2$)$.

Table 2. Frequency of intake of solid foods per week per age group. Percentages are calculated from the sample that was introduced to the corresponding food category. To specify rarely means a consumption with a lower frequency than 1 time per week.

\begin{tabular}{|c|c|c|c|c|c|c|}
\hline Food Categories Per Age & $n$ & Every Day & 5-6 Days & 3-4 Days & 1-2 Days & Rarely \\
\hline Cereals & 577 & & & & & \\
\hline 3-6 months & 51 & $14(27 \%)$ & $9(18 \%)$ & $6(12 \%)$ & $2(4 \%)$ & $20(39 \%)$ \\
\hline 7-11 months & 206 & $94(46 \%)$ & $21(10 \%)$ & $16(8 \%)$ & $12(6 \%)$ & $63(30 \%)$ \\
\hline 12-18 months & 320 & $157(49 \%)$ & $33(10 \%)$ & $22(7 \%)$ & $16(5 \%)$ & $92(29 \%)$ \\
\hline Fruits & 574 & & & & & \\
\hline $3-6$ months & 36 & $25(69 \%)$ & $9(25 \%)$ & $2(6 \%)$ & $0(0 \%)$ & $0(0 \%)$ \\
\hline 7-11 months & 211 & $167(79 \%)$ & $30(14 \%)$ & $10(5 \%)$ & $4(2 \%)$ & $0(0 \%)$ \\
\hline 12-18 months & 327 & $246(75 \%)$ & $65(20 \%)$ & $13(4 \%)$ & $3(1 \%)$ & $0(0 \%)$ \\
\hline
\end{tabular}


Table 2. Cont.

\begin{tabular}{|c|c|c|c|c|c|c|}
\hline Food Categories Per Age & $n$ & Every Day & 5-6 Days & 3-4 Days & 1-2 Days & Rarely \\
\hline Vegetables & 545 & & & & & \\
\hline $3-6$ months & 25 & $16(64 \%)$ & $7(28 \%)$ & $2(8 \%)$ & $0(0 \%)$ & $0(0 \%)$ \\
\hline 7-11 months & 199 & $150(75 \%)$ & $31(16 \%)$ & $13(7 \%)$ & $5(2 \%)$ & $0(0 \%)$ \\
\hline $12-18$ months & 321 & $216(67 \%)$ & $68(21 \%)$ & $25(8 \%)$ & $10(3 \%)$ & $2(1 \%)$ \\
\hline Yogurt & 468 & & & & & \\
\hline $3-6$ months & 15 & $4(27 \%)$ & $6(40 \%)$ & $2(13 \%)$ & $3(20 \%)$ & $0(0 \%)$ \\
\hline 7-11 months & 159 & $68(43 \%)$ & $46(29 \%)$ & $27(17 \%)$ & $12(7 \%)$ & $6(4 \%)$ \\
\hline 12-18 months & 294 & $174(59 \%)$ & $62(21 \%)$ & $40(14 \%)$ & $13(4 \%)$ & $5(2 \%)$ \\
\hline Meat & 490 & & & & & \\
\hline 3-6 months & 13 & $4(31 \%)$ & $4(31 \%)$ & $4(31 \%)$ & $1(8 \%)$ & $0(0 \%)$ \\
\hline 7-11 months & 179 & $50(28 \%)$ & $43(24 \%)$ & $64(36 \%)$ & $19(10 \%)$ & $3(2 \%)$ \\
\hline $12-18$ months & 298 & $46(15 \%)$ & $82(28 \%)$ & $133(45 \%)$ & $36(12 \%)$ & $1(0 \%)$ \\
\hline Cheese & 252 & & & & & \\
\hline 3-6 months & 3 & $0(0 \%)$ & $1(33 \%)$ & $1(33 \%)$ & $0(0 \%)$ & $1(33 \%)$ \\
\hline 7-11 months & 35 & $1(3 \%)$ & $4(11 \%)$ & $10(29 \%)$ & $13(37 \%)$ & $7(20 \%)$ \\
\hline $12-18$ months & 214 & $14(6 \%)$ & $41(19 \%)$ & $53(25 \%)$ & $70(33 \%)$ & $36(17 \%)$ \\
\hline Fish & 422 & & & & & \\
\hline 3-6 months & 5 & $0(0 \%)$ & $2(40 \%)$ & $3(60 \%)$ & $0(0 \%)$ & $0(0 \%)$ \\
\hline 7-11 months & 121 & $6(5 \%)$ & $19(16 \%)$ & $53(44 \%)$ & 37 (31\%) & $6(5 \%)$ \\
\hline $12-18$ months & 296 & $15(5 \%)$ & $58(20 \%)$ & $134(45 \%)$ & $85(29 \%)$ & $4(1 \%)$ \\
\hline Eggs & 323 & & & & & \\
\hline 3-6 months & 4 & $0(0 \%)$ & $1(25 \%)$ & $1(25 \%)$ & $1(25 \%)$ & $1(25 \%)$ \\
\hline 7-11 months & 61 & $0(0 \%)$ & $2(3 \%)$ & $6(10 \%)$ & $39(64 \%)$ & $14(23 \%)$ \\
\hline $12-18$ months & 258 & $1(0 \%)$ & $6(2 \%)$ & $33(13 \%)$ & $183(71 \%)$ & $35(14 \%)$ \\
\hline Legumes & 300 & & & & & \\
\hline 3-6 months & 4 & $0(0 \%)$ & $0(0 \%)$ & $1(25 \%)$ & $1(25 \%)$ & $2(50 \%)$ \\
\hline 7-11 months & 51 & $1(2 \%)$ & $6(12 \%)$ & $10(20 \%)$ & $27(53 \%)$ & $7(14 \%)$ \\
\hline $12-18$ months & 245 & $1(1 \%)$ & $15(6 \%)$ & $56(23 \%)$ & $138(56 \%)$ & $35(14 \%)$ \\
\hline
\end{tabular}

\subsubsection{Home-Prepared Feeding Practices}

Of all children, 586 (93\%) were given home-prepared foods at least once per week, whereas $7 \%$ were never fed home-prepared food (Table 3). The home-prepared foods were mainly prepared by the responsible parent $(66 \%)$, occasionally it alternated between the responsible parent and someone else (21\%), and for the minority, it was done by someone else (13\%). For 36\% (211 cases), salt was added to the home-cooked foods. In the age range from 3-6 months, salt was added in 13 cases (30\%), from 7-11 months in 57 cases (26\%), and in 141 cases from $12-18$ months (43\%).

Table 3. Home-prepared feeding practices per age group.

\begin{tabular}{ccc}
\hline Age Group & Home-Prepared Food, $\boldsymbol{n}(\mathbf{\%})$ & Never Home-Prepared Food, $\boldsymbol{n} \mathbf{( \% )}$ \\
\hline $3-6$ months & $43(77 \%)$ & $13(23 \%)$ \\
$7-11$ months & $216(94 \%)$ & $14(6 \%)$ \\
$12-18$ months & $327(95 \%)$ & $17(5 \%)$ \\
Total & $586(93 \%)$ & $44(7 \%)$ \\
\hline
\end{tabular}

As shown in Figure 2, in the age groups from 3-6 months and 7-11 months, more than half of the infants were fed with home-prepared puréed fruit every day, and for about a quarter five to six days a week. The percentages were slightly lower in toddlers from 
12-18 months old, where simultaneously the percentage of toddlers that was rarely/never fed with fruit purées was higher (15\%) (Figure 2).

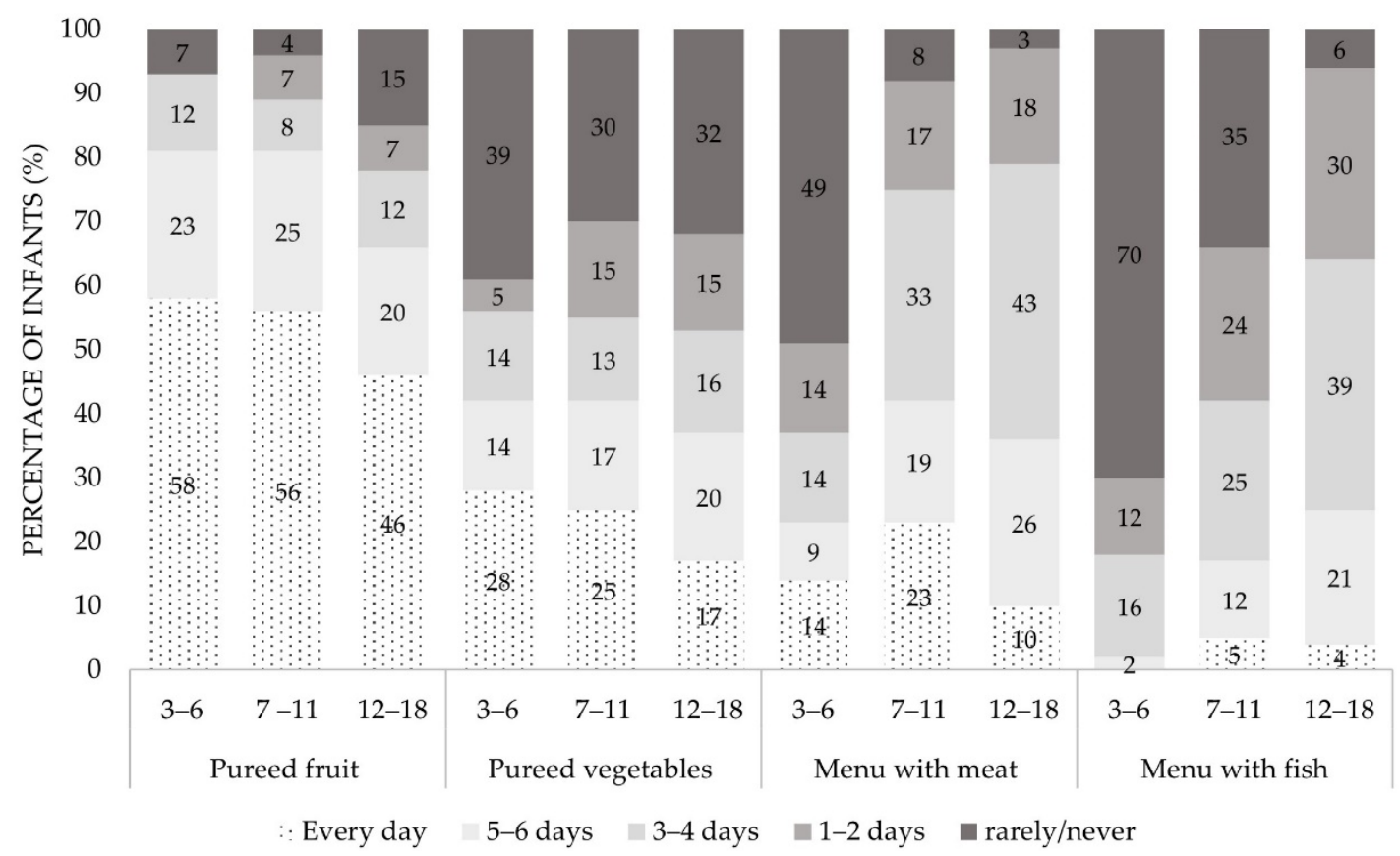

Figure 2. Frequency of intake of home-prepared purées and menus per week. Total $n=586,3-6$ months: $n=43$, 7-11 months: $n=216,12-18$ months: $n=327$. To specify rarely/never means a consumption with a lower frequency than 1 time per week or even no consumption at all. Percentages are rounded.

Home-prepared puréed vegetables were less common to offer daily to children, as compared to home-prepared fruits: in $28 \%, 25 \%$, and $17 \%$ of the children from 3-6, 7-11, and 12-18 months, respectively. The percentages of infants and toddlers that were rarely/never fed with home-prepared vegetables were higher as compared to fruits, ranging from 30-39\%.

Approximately half of the infants between 3-6 months (49\%) were rarely/never fed with meat. On the contrary, the percentage of children that were fed meat three to four days a week, increased from $14 \%$ in the first six months of life, to $33 \%$ and $43 \%$ in the subsequent age groups 7-11 and 12-18 months, respectively. Most of the infants between 3-6 months were rarely/never fed with fish $(70 \%)$. However, this percentage was halved in infants of 7-11 months of age, and close to zero (6\%) in toddlers of 12-18 months of age. The percentages of toddlers (12-18 months) fed with fish were remarkably high, with $64 \%$ of them being fed with fish three or more times a week (Figure 2).

\subsection{Pressure to Eat}

The reliability value for the pressure to eat scale was acceptable $(C R=0.75)$. Overall, the pressure to eat was rated by the parents as moderately high (3.46 \pm 0.82$)$. Values for the three items are shown in Table 4.

Table 4. Descriptive statistics of pressure to eat scale and its items $(n=630)$.

\begin{tabular}{cc}
\hline Pressure to Eat Scale and Its Items ${ }^{\mathbf{1}}$ & Mean \pm SD \\
\hline My child should always eat all of the food & $3.45 \pm 1.13$ \\
I try my best to make sure my child eats enough & $4.01 \pm 0.88$ \\
My child would eat much less if I do not pay attention to the feeding & $2.93 \pm 1.20$
\end{tabular}

${ }^{1}$ Items scored 1-5 using a 5-point Likert scale, with 1 = "strongly disagree", 2 = "disagree", 3 = "neither agree nor disagree", $4=$ "agree" and $5=$ "strongly agree". 


\subsection{Associations between Sample Characteristics, Feeding Practices and Pressure to Eat}

It was tested whether sample characteristics (both characteristics of the children and the responsible parents, as explained in Table 1) influenced the timing of the introduction of complementary foods. None of the characteristics affected the age of introduction to solids (all $p>0.05)$, except for the parents' gender $\left(\mathrm{F}_{1,628}=11.83 ; p<0.01\right)$. Fathers started on average 0.6 months later with the introduction of solids (5.65 \pm 2.28 months) as compared to mothers $(5.07 \pm 1.53$ months).

Furthermore, possible relevant associations between sample characteristics and parental pressure to eat were investigated. Higher levels of pressure to eat were related to lower infant's birth weight $(\mathrm{r}=-0.10, p=0.01)$ and lower current weight percentiles $(\mathrm{r}=-0.10$, $p=0.01)$. Higher pressure to eat ratings were found in female infants $\left(\mathrm{F}_{1,628}=5.67, p=0.02\right)$, parents below the age of 30 years $\left(\mathrm{F}_{1,628}=3.68, p=0.05\right)$, and full-time workers $\left(\mathrm{F}_{1,483}=8.55\right.$, $p<0.01)$. Also, there were significant differences in pressure to eat among the several regions in Spain $\left(\mathrm{F}_{6,623}=2.81, p=0.01\right)$. In the South of Spain, the pressure to eat was rated the highest $(3.57 \pm 0.82)$ and post-hoc LSD showed that pressure to eat in the South significantly differed from the Canary Islands (mean difference $0.61 \pm 0.28$ ), the North (mean difference $0.37 \pm 0.13$ ) and the North-West (mean difference $0.31 \pm 0.13$ ) of Spain. Significant associations tested with one-way ANOVA between sample characteristics and pressure to eat are shown in Table 5 . The pressure to eat was not significantly associated with the infants' age, position between brothers and sisters, daycare attendance, parents' gender, city size, educational level, monthly income, and marital status (all $p>0.05$ ).

Table 5. One-way ANOVA testing for the effects of sample characteristics on the pressure to eat. Only significant results are shown

\begin{tabular}{|c|c|c|c|c|c|}
\hline Variable & Characteristics & & Mean \pm SD & F-Value & $p$-Value \\
\hline \multirow[t]{13}{*}{ Pressure to eat } & Gender infant & Girl & $3.54 \pm 0.84$ & $\mathrm{~F}_{1,628}=5.67$ & 0.02 \\
\hline & & Boy & $3.39 \pm 0.81$ & & \\
\hline & Parent's age & $\leq 30$ years & $3.61 \pm 0.78$ & $\mathrm{~F}_{1,628}=3.68$ & 0.05 \\
\hline & & $>30$ years & $3.44 \pm 0.83$ & & \\
\hline & Job intensity & Full-time & $3.50 \pm 0.79$ & $\mathrm{~F}_{1,483}=8.55$ & $<0.01$ \\
\hline & & Part-time/per hours & $3.25 \pm 0.76$ & & \\
\hline & Region & North & $3.20 \pm 0.81$ & $\mathrm{~F}_{6,623}=2.81$ & 0.01 \\
\hline & & North-East & $3.47 \pm 0.78$ & & \\
\hline & & East & $3.56 \pm 0.81$ & & \\
\hline & & South & $3.57 \pm 0.82$ & & \\
\hline & & Center & $3.51 \pm 0.77$ & & \\
\hline & & North-West & $3.26 \pm 0.95$ & & \\
\hline & & Canary Islands & $2.96 \pm 1.20$ & & \\
\hline
\end{tabular}

Even though differences were not significant, the pressure to eat was higher in parents with primary education (mean value $=3.55$ ), as compared to those with secondary education (mean value $=3.46$ ) and a university degree (mean value $=3.45)$. Similarly, the pressure was also faintly higher in the group with income lower than $1000 €$ (mean value $=3.48$ ) as compared to the group with incomes higher than $1000 €$ (mean value $=3.47$ ).

Pressure to eat was not associated with the timing of introduction to solids. However, the pressure to eat was associated with the introduction of some complementary foods (fruits, vegetables, and meat) in infants and toddlers of 6-18 months old. Higher values of pressure to eat were found in those children that were not introduced to these three food types (Table 6).

Interestingly, the pressure to eat tended to take place less (F1,628 $=3.83 ; \mathrm{p}=0.05)$ when children were exposed to any home-prepared foods $(3.45 \pm 0.82)$ compared to children that were not exposed to any home-prepared foods $(3.70 \pm 0.83)$. 
Table 6. One-way ANOVA testing for the effects of the introduction of several food categories on the pressure to eat in infants and toddlers from 6-18 months old, $n=580$. Only significant results are shown.

\begin{tabular}{cccccc}
\hline Variable & Food Category & $\begin{array}{c}\text { Child Does Not Eat This Food } \\
\text { Mean } \pm \text { SD }\end{array}$ & $\begin{array}{c}\text { Child Eats This Food } \\
\text { Mean } \pm \text { SD }\end{array}$ & F-Value & $p$-Value \\
\hline \multirow{2}{*}{ Pressure to eat } & Fruit & $3.88 \pm 0.69$ & $3.44 \pm 0.83$ & $\mathrm{~F}_{1,578}=4.22$ & 0.04 \\
& Vegetables & $3.74 \pm 0.72$ & $3.43 \pm 0.84$ & $\mathrm{~F}_{1,578}=4.78$ & 0.03 \\
& Meat & $3.64 \pm 0.80$ & $3.42 \pm 0.83$ & $\mathrm{~F}_{1,578}=5.37$ & 0.02 \\
\hline
\end{tabular}

\section{Discussion}

This study described complementary feeding practices and explored potential associations among parental and infant characteristics, feeding practices, and parental pressure to eat among Spanish infants and toddlers. Several important insights can be derived from our results.

First, we observed that the majority of the parents started with the introduction of complementary foods between four and six months old, which is consistent with European $[19,20]$ and Spanish recommendations $[29,30]$ and findings from Costantini et al. (2018) [24] in the UK and Italy. Similar to the results obtained in Norway [42], Denmark [44], Switzerland [47], and the Netherlands [55], solids were rarely given before the age of four months $(8 \%)$. On a related issue, early introduction (before the age of four months) in prior research has been associated with a younger maternal age $[23,47,49,53-55,81]$ and a lower educational level $[53-55,81,82]$. Our results could not confirm an association between timing of introduction and parental age nor educational level. We found that mothers tend to introduce solids at an earlier age than fathers. To our knowledge, this finding has not been investigated or found in previous research yet. There has been little research on the role of the father in infant feeding, as often only mothers are included in the analyses [83]. This is unfortunate since fathers also play a key role in the development and feeding habits of their children $[84,85]$.

As for the types of first introduced solids, our findings were consistent with an earlier study conducted in Spain [76]. In particular, cereals along with fruits were the most common first given solids. This is also in line with evidence from other countries such as UK, Ireland, and Canada $[40,48,50,53]$. In contrast, Turkish infants were fed yogurt first [86], and studies in France [51,52,87] and Germany [87] showed that vegetables were also a prominent food category to start with. It is striking that yogurt was introduced around the age of seven months, while it is advised in Spain to postpone the introduction until the age of nine months [29,30]. In addition, this study showed that Spanish parents wait for the introduction of fish and eggs to a later age stage. Indeed, these were the Spanish recommendations in the past [29], but current European recommendations are to introduce potentially allergenic foods (e.g., fish, eggs, peanut) no later than other solids [21]. Parents might be a bit reluctant to provide those foods due to the changeability of feeding guidelines that leads to confusion, the use of multiple sources of information, or simply concerned about the infant's readiness for certain foods [83].

Our findings were consistent with the Spanish recommendations for the frequency of food intake of cereals, fruit, vegetables, meat, and fish [29,30], although not always exact amounts are recommended. Given the fact that breast milk or infant formula are still the most important dairy sources during the complementary feeding period, the consumption frequency of yogurt might need some attention [29,30]. In particular, the ENALIA study (2017) found a similar intake of yogurt, as $41.6 \%$ and $56.1 \%$ of Spanish children between 6-11 months and 12-35 months consumed yogurt once a day, respectively [61]. According to the IFS survey, $68.0 \%$ of British infants between $8-10$ months of age consumed yogurt at least once a day [48]. A high yogurt intake along with an adequate milk consumption could lead to a higher than desirable protein intake. An excessive intake of protein in infancy was found in previous studies $[59,88,89]$ and has been related to higher levels of overweight and obesity in later life [90]. 
Almost all children were fed with home-prepared foods at least once a week, where puréed fruit was in each age category most frequently prepared. One plausible explanation for this could be that fruit purées are easier to prepare as compared to meat and fish purées. An important issue in preparing infant food at home relates to the addition of salt. Salt addition is discouraged in infants up to two years of age; not only because they are too immature and unable to excrete an overload of salt $[20,88]$, but also to prevent encouragement of unhealthy preferences [20,91]. Contrary to the recommendations to avoid the addition of salt, especially during the first year of life [30], a third of the parents surveyed in our study admitted adding salt when cooking at home. This percentage was lower (11\%) in Spanish infants according to the ENALIA study (2017) [61].

Consistent with previous evidence [92-96], the pressure to eat was negatively correlated to the child's current weight percentile. Because of the cross-sectional design of our study, the direction of the relationship cannot be established. It could well be that it concerns a vicious circle. Parents might react to the weight of the child by pressuring them to eat. This supports the thought that parental feeding practices are a result as well as a predictor of child weight, where a pressuring feeding style is counterproductive [97,98]. In addition, we found that pressure to eat was negatively associated with the infants' birth weight. The same associations for birth weight were found earlier with a pressuring feeding style in a cross-sectional study [99]. These observations may imply that parental pressure to eat is somehow already developed soon after the child is born and thus may suggest that it is a result rather than a predictor of child weight. A noteworthy outcome of the present study that needs to be stressed out is that pressuring feeding practices were the highest in the South of Spain and differed significantly from the North and North-West of Spain. Interestingly, higher rates of childhood obesity can be found in southern areas of Spain, as compared to the northern areas [100]. This may imply that, in line with the study by McPhie et al. (2012) [101], the pressure to eat in early life could lead to weight gain later on.

Our study adds to the literature by identifying other relevant variables related to the pressure to eat. Unlike prior research that did not find differences in infant's or children's gender [99,102-104], we found that pressure to eat was higher in female infants. As parental pressure to eat has been shown to be positively correlated to their concern about their children being underweight [94], we could argue that parents might be more concerned about girls becoming underweight and thereby putting more pressure on them than on boys. Still, further studies are needed in this regard. Furthermore, parental pressure was higher among younger parents, which is consistent with findings from Brown and Lee (2013) [105] in the UK that showed that maternal age was inversely associated with an encouraging feeding style. We also found that parents working full-time exerted a major pressure to eat, as compared to those working part-time. Lack of time and impatience might be a plausible explanation for this finding, but little is known about the potential role parental employment plays in infant complementary feeding practices. Importantly, we found that infants' exposure to home-prepared meals tended to be associated with lower pressure to eat. In Synnott et al. (2007) [106], mothers explained that they prepared meals at home to ensure their baby would like the food. Even though the pressure to eat was only slightly higher in lower-income groups and with lower levels of education, our differences were not significant in line with prior research [101,107-110]. Still, other studies have found significant differences [111-116]. Given these inconsistent findings, we encourage researchers to deepen into the relationship of pressure to eat, parents' income, and educational level.

There are strengths and limitations to this study that need to be considered. The present study is strengthened by the fact that a nationally representative sample was gathered, as 630 final responses distributed over each region in Spain were included in the analyses. The sample consisted of both mothers and fathers which provides new insights about fathers' feeding practices and how these differ from mothers' feeding practices. Furthermore, before conducting the online survey, the questionnaire was tested and validated where 
after the content was checked and modified. However, it has been shown previously that observed and reported parental feeding styles and practices might not always be in congruence $[66,117,118]$. Therefore, it must be noted that there was a chance of reporting bias. Also, because the current study used a cross-sectional approach, it is difficult to make causal inferences since variables were measured at one single point in time. Thus, longitudinal studies are recommended to establish the direction of relations between infant weight (trajectories) and parental pressure to eat. Finally, future research on infant feeding practices could include fathers too and examine other determinants of parental pressure to eat.

\section{Conclusions}

Complementary feeding practices were identified and explored in parents with infants and toddlers from 3-18 months in Spain. In line with the European and Spanish recommendations, the timing of introduction to solids occurred generally between four and six months of age. Fathers seem to introduce solids later than mothers. Comparable to many other countries, cereals and fruits were the most common first given solids. Parents provide yogurt earlier than recommended, while they wait for the introduction of fish and eggs. Frequent consumption of yogurt in addition to adequate milk consumption could be worrisome due to possibly excessive levels of protein intake. The high prevalence of salt added while preparing home-made complementary food needs to be addressed. Interestingly, higher levels of parental pressure to eat were found in female infants, younger parents, parents with a full-time job, the southern regions of Spain, and in infants that were not fed with home-prepared foods.

Hopefully, our insights underline the importance of clear and more specific feeding recommendations that can support health care professionals and parents in promoting effective strategies to improve parental feeding practices. In particular, national and regional guidelines would have to continuously incorporate the latest scientific evidence from experts' bodies (e.g., EFSA, ESPGHAN) in key areas such as the right moment to introduce allergens (e.g., fish and eggs) in infants' diet. Health care professionals may advise parents, particularly younger and less experienced ones working full-time, about the potential problems associated with pressuring infants to eat (e.g., eating disorders, risk of overweight). At a community level, educational initiatives that stress public awareness about when, what and how to feed babies are encouraged through communication campaigns and tools that instruct parents, for example, on how to make adequate nutritional and healthy adaptations of their traditional/cultural recipes for their infants.

Author Contributions: Conceptualization, M.K., S.R., and L.M.S.-S.; methodology, M.J.B., L.M.S.S., and S.R.; validation, M.K., M.J.B., and J.F.H.-V.; formal analysis, M.K., M.J.B., and J.F.H.-V.; investigation, M.J.B. and J.F.H.-V.; data curation, M.K., M.J.B., and J.F.H.-V.; writing —original draft preparation, M.K., L.M.S.-S., and S.R.; writing-review and editing, M.K., S.R., L.M.S.-S., and M.J.B.; visualization, M.K., S.R., and L.M.S.-S.; supervision, L.M.S.-S. All authors have read and agreed to the published version of the manuscript.

Funding: This research was funded by Hero AG (Switzerland).

Institutional Review Board Statement: The study was conducted according to the guidelines of the Declaration of Helsinki, and the protocol was approved by the Ethics Committee of the University of Murcia (CEI 1011/2014).

Informed Consent Statement: Informed consent was obtained from all subjects involved in the study.

Data Availability Statement: The data presented in this study are available on request from the corresponding author.

Acknowledgments: We would like to thank all parents who participated in this study.

Conflicts of Interest: M.K., M.J.B., J.F.H.-V., and L.M.S.-S. declare a conflict of interest because the present study was funded by Hero Group. M.K., M.J.B., J.F.H.-V., and L.M.S.-S. are members of the Research and Nutrition Department of Hero Group. S.R. declares no conflict of interest. 


\section{References}

1. Caprio, S.; Santoro, N.; Weiss, R. Childhood obesity and the associated rise in cardiometabolic complications. Nat. Metab. 2020, 2, 223-232. [CrossRef] [PubMed]

2. Narzisi, K.; Simons, J. Interventions that prevent or reduce obesity in children from birth to five years of age: A systematic review. J. Child Health Care 2020, 1367493520917863. [CrossRef] [PubMed]

3. Pérez-Farinós, N.; Lopez-Sobaler, A.M.; Dal Re, M.A.; Villar, C.; Labrado, E.; Robledo, T.; Ortega, R.M. The ALADINO Study: A National Study of Prevalence of Overweight and Obesity in Spanish Children in 2011. BioMed Res. Int. 2013, 163687. [CrossRef]

4. Sánchez-Cruz, J.-J.; Jiménez-Moleón, J.J.; Fernández-Quesadad, F.; Sáncheza, M.J. Prevalencia de obesidad infantil y juvenil en España en 2012. Rev. Esp. Cardiol. 2014, 66, 371-376. [CrossRef]

5. Aranceta-Bartrina, J.; Pérez-Rodrigo, C. La obesidad infantil: Una asignatura pendiente. Rev. Esp. Cardiol. 2018, 71, 888-891. [CrossRef]

6. Agencia Española de Seguridad Alimentaria y Nutrición (AESAN): Estudio Aladino 2019: Estudio sobre Alimentación, Actividad Física, Desarrollo Infantil y Obesidad en España 2019. Available online: https://www.aesan.gob.es/AECOSAN/docs/ documentos/nutricion/observatorio/Informe_Aladino_2019.pdf (accessed on 5 January 2021).

7. Spinelli, A.; Buoncristiano, M.; Kovacs, V.A.; Yngve, A.; Spiroski, I.; Obreja, G.; Sant'Angelo, V.F. Prevalence of severe obesity among primary school children in 21 European countries. Obes. Facts 2009, 12, 244-258. [CrossRef]

8. Schwartz, C.; Scholtens, P.A.M.J.; Lalanne, A.; Weenen, H.; Nicklaus, S. Development healthy eating habits early in life. Review of recent evidence and selected guidelines. Appetite 2011, 57, 796-807. [CrossRef] [PubMed]

9. Robinson, S.; Fall, C. Infant nutrition and later health: A review of current evidence. Nutrients 2012, 4, 859-874. [CrossRef]

10. World Health Organization (WHO). Infant and Young Child Nutrition: Global Strategy on Infant and Young Child Feeding; World Health Organization, Fifty Fifth World Health Assembly: Geneva, Switzerland, 2002.

11. D'Auria, E.; Borsani, B.; Pendezza, E.; Bosetti, A.; Paradiso, L.; Zuccotti, G.V.; Verduci, E. Complementary feeding: Pitfalls for health outcomes. Int. J. Environ. Res. Public Health 2020, 17, 7931. [CrossRef]

12. Nicklaus, S. Children's acceptance of new foods at weaning. Role of practices of weaning and of food sensory properties. Appetite 2011, 57, 812-815. [CrossRef]

13. Maier-Nöth, A.; Schaal, B.; Leathwood, P.; Issanchou, S. The lasting influences of early food-related variety experience: A longitudinal study of vegetable acceptance from 5 months to 6 years in two populations. PLoS ONE 2016, 11, e0151356. [CrossRef] [PubMed]

14. Mennella, J.A.; Beauchamp, G.K. The role of early life experiences in flavor perception and delight. In Obesity Prevention, 1st ed.; Dubé, L., Bechara, A., Dagher, A., Drewnowski, A., Eds.; Elsevier Inc.: Philadelphia, PA, USA, 2010; pp. 203-217. [CrossRef]

15. Nicklaus, S.; Remy, E. Early origins of overeating: Tracking between early food habits and later eating patterns. Curr. Obes. Rep. 2013, 2, 179-184. [CrossRef]

16. Nicklaus, S. The role of food experiences during early childhood in food pleasure learning. Appetite 2016, 104, 3-9. [CrossRef] [PubMed]

17. Switkowski, K.M.; Gingras, V.; Rifas-Shiman, S.L.; Oken, E. Patterns of Complementary Feeding Behaviors Predict Diet Quality in Early Childhood. Nutrients 2020, 12, 810. [CrossRef]

18. Pan American Health Organization and World Health Organization (PAHO \& WHO). Guiding Principles for Complementary Feeding of the Breastfed; World Health Organization: Washington, DC, USA, 2001.

19. Agostoni, C.; Decsi, T.; Fewtrell, M.; Goulet, O.; Kolacek, S.; Koletzko, B.; Michaelsen, K.F.; Moreno, L.; Puntis, J.; Rigo, J.; et al. Complementary feeding: A commentary by the ESPGHAN Committee on Nutrition. J. Pediatr. Gastroenterol. Nutr. 2008, 46, 99-110. [CrossRef] [PubMed]

20. Fewtrell, M.; Bronsky, J.; Campoy, C.; Domellöf, M.; Embleton, N.; Mis, N.F.; Hojsak, I.; Hulst, J.M.; Indrio, F.; Lapillonne, A.; et al. Complementary feeding: A position paper by the European Society for Paediatric Gastroenterology, Hepatology, and Nutrition (ESPGHAN) Committee on nutrition. J. Pediatr. Gastroenterol. Nutr. 2007, 64, 119-132. [CrossRef]

21. EFSA Panel on Nutrition, Novel Foods and Food Allergens (NDA); Castenmiller, J.; de Henauw, S.; Hirsch-Ernst, K.I.; Kearney, J.; Knutsen, H.K.; Maciuk, A.; Mangelsdorf, I.; McArdle, H.J.; Naska, A.; et al. Appropriate age range for introduction of complementary feeding into an infant's diet. EFSA J. 2019, 17, e05780. [CrossRef]

22. Koletzko, B.; Hirsch, N.L.; Jewell, J.M.; Dos Santos, Q.; Breda, J.; Fewtrell, M.; Weber, M.W. National Recommendations for Infant and Young Child Feeding in the World Health Organization European Region. J. Pediatr. Gastroenterol. Nutr. 2020, 71, 672. [CrossRef] [PubMed]

23. Alder, E.M.; Williams, F.L.R.; Anderson, A.S.; Forsyth, S.; Florey, C.D.V.; van der Velde, P. What influences the timing of the introduction of solid food to infants? Br. J. Nutr. 2004, 92, 527. [CrossRef]

24. Costantini, C.; Harris, G.; Reddy, V.; Akehurst, L.; Fasulo, A. Introducing complementary foods to infants: Does age really matter? A look at feeding practices in two European communities: British and Italian. Child Care Pract. 2018, 25, 1-16. [CrossRef]

25. Foterek, K.; Hilbig, A.; Alexy, U. Breast-feeding and weaning practices in the DONALD Study. J. Pediatr. Gastroenterol. Nutr. 2014, 58, 361-367. [CrossRef] [PubMed]

26. White, J.M.; Bégin, F.; Kumapley, R.; Murray, C.; Krasevec, J. Complementary feeding practices: Current global and regional estimates. Matern. Child Nutr. 2017, 13, e12505. [CrossRef] [PubMed]

27. Netting, M.J.; Makrides, M. Complementary foods: Guidelines and practices. In Complementary Feeding: Building the Foundations for a Healthy Life; Black, R.E., Makrides, M., Ong, K.K., Eds.; Karger Publishers: Basel, Switzerland, 2017; pp. 1-12. [CrossRef] 
28. Domellöf, M.; Braegger, C.; Campoy, C.; Colomb, V.; Decsi, T.; Fewtrell, M.; Hojsak, I.; Mihatsch, W.; Molgaard, C.; Shamir, R.; et al. Iron requirements of infants and toddlers. J. Pediatr. Gastroenterol. Nutr. 2014, 58, 119-129. [CrossRef]

29. Asociación Española de Pediatría (AEP). Manual Práctico de Nutrición en Pediatría; AEP Asociación Española de Pediatría: Madrid, Spain, 2007.

30. Asociación Española de Pediatría (AEP). Recomendaciones de la Asociación Española de Pediatría Sobre la Alimentación Complementaria; Comité de Lactancia Materna y Comité de Nutrición de la Asociación Española de Pediatría, AEP Asociación Española de Pediatría: Madrid, Spain, 2018.

31. World Health Organization (WHO): Infant and Young Child Feeding. Available online: https://www.who.int/en/news-room/ fact-sheets / detail/infant-and-youngchild-feeding (accessed on 5 January 2021).

32. Burns, J.; Emerson, J.A.; Amundson, K.; Doocy, S.; Caulfield, L.E.; Klemm, R.D.W. A qualitative analysis of barriers and facilitators to optimal breastfeeding and complementary feeding practices in South Kivu, Democratic Republic of Congo. Food Nutr. Bull. 2016, 37, 119-131. [CrossRef] [PubMed]

33. Egyir, B.K.; Ramsay, S.A.; Bilderback, B.; Safaii, S.A. Complementary feeding practices of mothers and their perceived impacts on young children: Findings from KEEA district of Ghana. Matern. Child Health J. 2016, 20, 1886-1894. [CrossRef] [PubMed]

34. Issaka, A.I.; Agho, K.E.; Page, A.N.; Burns, P.L.; Stevens, G.J.; Dibley, M.J. Determinants of suboptimal complementary feeding practices among children aged 6-23 months in seven francophone West African countries. Matern. Child Nutr. 2015, 11, 31-52. [CrossRef]

35. Kimani-Murage, E.W.; Madise, N.J.; Fotso, J.-C.; Kyobutungi, C.; Mutua, M.K.; Gitau, T.M.; Yatich, N. Patterns and determinants of breastfeeding and complementary feeding practices in urban informal settlements, Nairobi Kenya. BMC Public Health 2011, 11, 396. [CrossRef]

36. Vaahtera, M.; Kulmala, T.; Hietanen, A.; Ndekha, M.; Cullinan, T.; Salin, M.L.; Ashorn, P. Breastfeeding and complementary feeding practices in rural Malawi. Acta Paediatr. 2001, 90, 328-332. [CrossRef] [PubMed]

37. Duong, D.V.; Binns, C.W.; Lee, A.H. Introduction of complementary food to infants within the first six months postpartum in rural Vietnam. Acta Paediatr. 2005, 94, 1714-1720. [CrossRef]

38. Gardner, H.; Green, K.; Gardner, A. Infant feeding practices of Emirati women in the rapidly developing city of Abu Dhabi, United Arab Emirates. Int. J. Environ. Res. Public Health 2015, 12, 10923-10940. [CrossRef]

39. Radwan, H. Patterns and determinants of breastfeeding and complementary feeding practices of Emirati Mothers in the United Arab Emirates. BMC Public Health 2013, 13, 171. [CrossRef]

40. Friel, J.K.; Isaak, C.A.; Hanning, R.; Miller, A. Complementary food consumption of Canadian infants. Open Nutr. J. 2009, 3 , 11-16. [CrossRef]

41. Siega-Riz, A.M.; Deming, D.M.; Reidy, K.C.; Fox, M.K.; Condon, E.; Briefel, R.R. Food consumption patterns of infants and toddlers: Where are we now? J. Am. Diet. Assoc. 2010, 110, S38-S51. [CrossRef]

42. Helle, C.; Hillesund, E.R.; Øverby, N.C. Timing of complementary feeding and associations with maternal and infant characteristics: A Norwegian cross-sectional study. PLoS ONE 2018, 13, e0199455. [CrossRef] [PubMed]

43. Klingberg, S.; Ludvigsson, J.; Brekke, H.K. Introduction of complementary foods in Sweden and impact of maternal education on feeding practices. Public Health Nutr. 2017, 20, 1054-1062. [CrossRef] [PubMed]

44. Kronborg, H.; Foverskov, E.; Vaeth, M. Predictors for early introduction of solid food among Danish mothers and infants: An observational study. BMC Pediatr. 2014, 14, 243. [CrossRef] [PubMed]

45. Lande, B.; Andersen, L.F.; Baerug, A.; Trygg, K.U.; Lund-Larsen, K.; Veierød, M.B.; Bjørneboe, G.E.A. Infant feeding practices and associated factors in the first six months of life: The Norwegian infant nutrition survey. Acta Paediatr. 2003, 92, 152-161. [CrossRef] [PubMed]

46. Carletti, C.; Pani, P.; Monasta, L.; Knowles, A.; Cattaneo, A. Introduction of complementary foods in a cohort of infants in Northeast Italy: Do parents comply with WHO Recommendations? Nutrients 2017, 9, 34. [CrossRef] [PubMed]

47. Dratva, J.; Merten, S.; Ackermann-Liebrich, U. The timing of complementary feeding of infants in Switzerland: Compliance with the Swiss and the WHO guidelines. Acta Paediatr. 2006, 95, 818-825. [CrossRef] [PubMed]

48. McAndrew, F.; Thompson, J.; Fellows, L.; Large, A.; Speed, M.; Renfrew, M.J. Infant Feeding Survey 2010; The Health and Social Care Information Centre: Leeds, UK, 2012.

49. Giovannini, M.; Riva, E.; Banderali, G.; Scaglioni, S.; Veehof, S.; Sala, M.; Radaelli, G.; Agostoni, C. Feeding practices of infants through the first year of life in Italy. Acta Paediatr. 2004, 93, 492-497. [CrossRef] [PubMed]

50. O'Donovan, S.M.; Murray, D.M.; Hourihane, J.O.; Kenny, L.C.; Irvine, A.D.; Kiely, M. Adherence with early infant feeding and complementary feeding guidelines in the Cork BASELINE Birth Cohort Study. Public Health Nutr. 2015, 18, 2864-2873. [CrossRef] [PubMed]

51. Lange, C.; Visalli, M.; Jacob, S.; Chabanet, C.; Schlich, P.; Nicklaus, S. Maternal feeding practices during the first year and their impact on infants' acceptance of complementary food. Food Qual. Prefer. 2013, 29, 89-98. [CrossRef]

52. Schwartz, C.; Madrelle, J.; Vereijken, C.M.J.L.; Weenen, H.; Nicklaus, S.; Hetherington, M.M. Complementary feeding and “donner les bases du goût" (providing the foundation of taste). A qualitative approach to understand weaning practices, attitudes and experiences by French mothers. Appetite 2013, 71, 321-331. [CrossRef]

53. Tarrant, R.C.; Younger, K.M.; Sheridan-Pereira, M.; White, M.J.; Kearney, J.M. Factors associated with weaning practices in term infants: A prospective observational study in Ireland. Br. J. Nutr. 2010, 104, 1544-1554. [CrossRef] [PubMed] 
54. Rebhan, B.; Kohlhuber, M.; Schwegler, U.; Koletzko, B.V.; Fromme, H. Infant feeding practices and associated factors through the first 9 months of life in Bavaria, Germany. J. Pediatr. Gastroenterol. Nutr. 2009, 49, 467-473. [CrossRef] [PubMed]

55. Wang, L.; Van Grieken, A.; Van Der Velde, L.A.; Vlasblom, E.; Beltman, M.; L'Hoir, M.P.; Boere-Boonekamp, M.M.; Raat, H. Factors associated with early introduction of complementary feeding and consumption of non-recommended foods among Dutch infants: The BeeBOFT study. BMC Public Health 2019, 19, 388. [CrossRef]

56. Serra-Majem, L.; Ribas Barba, L.; Pérez-Rodrigo, C.; Roman Viñas, B.; Aranceta Bartrina, J. Hábitos alimentarios y consumo de alimentos en la población infantil y juvenil española (1998-2000): Variables socioeconómicas y geográficas. Med. Clín. 2003, 121, 126-131. [CrossRef]

57. Díez-Gañán, L.; Galán Labaca, I.; Domínguez, C.M.L.; Gandarillas Grande, A.; Zorrilla Torras, B.; Cebrián, F.A. Ingesta de alimentos, energía y nutrientes en la población de 5 a 12 años de la Comunidad de Madrid: Resultados de la Encuesta de Nutrición Infantil 2001-2002. Rev. Esp. Salud Publica 2007, 81, 543-558. [CrossRef]

58. Latorre-Millán, M.; Rupérez, A.I.; González-Gil, E.M.; Santaliestra-Pasías, A.; Vázquez-Cobela, R.; Gil Campos, M.; Aguilera, C.M.; Gil, Á.; Moreno, L.A.; Leis, R.; et al. Dietary Patterns and Their Association with Body Composition and Cardiometabolic Markers in Children and Adolescents: Genobox Cohort. Nutrients 2020, 12, 3424. [CrossRef]

59. Dalmau, J.; Moráis, A.; Martínez, V.; Peña-Quintana, L.; Varea, V.; Martínez, M.J.; Soler, B. Evaluación de la alimentación y consumo de nutrientes en menores de 3 años. Estudio piloto ALSALMA. An. Pediatr. 2014, 81, 22-31. [CrossRef] [PubMed]

60. Dalmau, J.; Peña-Quintana, L.; Moráis, A.; Martínez, V.; Varea, V.; Martínez, M.J.; Soler, B. Análisis cuantitativo de la ingesta de nutrientes en niños menores de 3 años. Estudio ALSALMA. An. Pediatr. 2015, 82, 255-266. [CrossRef]

61. Agencia Española de Consumo, Seguridad Alimentaria y Nutrición (AECOSAN). ENALIA: Encuesta Nacional de Consumo de Alimentos en Población Infantil y Adolescente 2012-2015; Ministerio de Sanidad, Servicios Sociales e Igualdad: Madrid, Spain, 2017.

62. López-Sobaler, A.M.; Aparicio, A.; González-Rodríguez, L.G.; Cuadrado-Soto, E.; Rubio, J.; Marcos, V.; Sanchidrián, R.; Santos, S.; Pérez-Farinós, N.; Re, M.Á.D.; et al. Adequacy of usual vitamin and mineral intake in Spanish children and adolescents: ENALIA study. Nutrients 2017, 9, 131. [CrossRef]

63. Madrigal, C.; Soto-Méndez, M.J.; Leis, R.; Hernández-Ruiz, Á.; Valero, T.; Villoslada, F.L.; De Victoria, E.M.; Moreno, J.M.; Ortega, R.M.; Ruiz-López, M.D.; et al. Dietary Intake, Nutritional Adequacy and Food Sources of Total Fat and Fatty Acids, and Relationships with Personal and Family Factors in Spanish Children Aged One to < 10 Years: Results of the EsNuPI Study. Nutrients 2020, 12, 2467. [CrossRef]

64. Thompson, A.L.; Mendez, M.A.; Borja, J.B.; Adair, L.S.; Zimmer, C.R.; Bentley, M.E. Development and validation of the infant feeding style questionnaire. Appetite 2009, 53, 210-221. [CrossRef] [PubMed]

65. Ventura, A.K.; Birch, L.L. Does parenting affect children's eating and weight status? Int. J. Behav. Nutr. Phys. Act. 2008, 5, 1-12. [CrossRef] [PubMed]

66. Sacco, L.M.; Bentley, M.E.; Carby-Shields, K.; Borja, J.B.; Goldman, B.D. Assessment of infant feeding styles among low-income African-American mothers: Comparing reported and observed behaviors. Appetite 2007, 49, 131-140. [CrossRef] [PubMed]

67. DiSantis, K.I.; Hodges, E.A.; Johnson, S.L.; Fisher, J.O. The role of responsive feeding in overweight during infancy and toddlerhood: A systematic review. Int. J. Obes. 2011, 35, 480-492. [CrossRef] [PubMed]

68. Ellis, J.M.; Galloway, A.T.; Webb, R.M.; Martz, D.M.; Farrow, C.V. Recollections of pressure to eat during childhood, but not picky eating, predict young adult eating behavior. Appetite 2016, 97, 58-63. [CrossRef] [PubMed]

69. Rodgers, R.F.; Paxton, S.J.; Massey, R.; Campbell, K.J.; Wertheim, E.H.; Skouteris, H.; Gibbons, K. Maternal feeding practices predict weight gain and obesogenic eating behaviors in young children: A prospective study. Int. J. Behav. Nutr. Phys. Act. 2013, 10, 24. [CrossRef]

70. Thompson, A.L.; Adair, L.S.; Bentley, M.E. Pressuring and restrictive feeding styles influence infant feeding and size among a low-income African-American sample. Obesity 2013, 21, 562-571. [CrossRef]

71. Bernal, M.J.; Román, S.; Klerks, M.; Iniesta, M.D.; Haro, J.F.; Bodenstab, S.; Sánchez-Siles, L.M. Elaboración de un instrumento para evaluar las prácticas de alimentación infantil en los primeros 18 meses de vida en España. Estudio HIDANS. [XVII Congreso de la Sociedad Española de Investigación en Nutrición y Alimentación en Pediatría (SEINAP), 6 y 7 de octubre de 2017]. Rev. Esp. Pediatr. 2017, 73, 261-263.

72. Román, S.; Sánchez-Siles, L.M. Parents' choice criteria for infant food brands: A scale development and validation. Food Qual. Prefer. 2018, 64, 1-10. [CrossRef]

73. Baughcum, A.E.; Powers, S.W.; Johnson, S.B.; Chamberlin, L.A.; Deeks, C.M.; Jain, A.; Whitaker, R.C. Maternal feeding practices and beliefs and their relationships to overweight in early childhood. J. Dev. Behav. Pediatr. 2001, 22, 391-408. [CrossRef]

74. Birch, L.L.; Fisher, J.O.; Grimm-Thomas, K.; Markey, C.N.; Sawyer, R.; Johnson, S.L. Confirmatory factor analysis of the Child Feeding Questionnaire: A measure of parental attitudes, beliefs and practices about child feeding and obesity proneness. Appetite 2001, 36, 201-210. [CrossRef] [PubMed]

75. Llewellyn, C.H.; van Jaarsveld, C.H.M.; Johnson, L.; Carnell, S.; Wardle, J. Development and factor structure of the Baby Eating Behaviour Questionnaire in the Gemini birth cohort. Appetite 2011, 57, 388-396. [CrossRef]

76. van den Boom, S.A.M.; Kimber, A.C.; Morgan, J.B. Weaning practices in children up to 19 months of age in Madrid. Acta Paediatr. 1995, 84, 853-858. [CrossRef]

77. Beatty, P.; Willis, G.B. Research synthesis: The practice of cognitive interviewing. Public Opin. Q. 2007, 71, 287-311. [CrossRef] 
78. Dickin, K.L.; Larios, F.B.S.; Parra, P.A. Cognitive interviewing to enhance comprehension and accuracy of responses to a spanish-language nutrition program evaluation tool. J. Nutr. Educ. Behav. 2015, 47, 465-471. [CrossRef] [PubMed]

79. World Health Organization (WHO). WHO Child Growth Standards: Length/Height-for-Age, Weight for-Age, Weight-for-Length, Weight-for-Height and Body Mass Index-for-Age: Methods and Development; World Health Organization: Geneva, Switzerland, 2006.

80. Bagozzi, R.P.; Yi, Y. On the evaluation of structural equation models. J. Acad. Mark. Sci. 1988, 16, 74-94. [CrossRef]

81. Betoko, A.; Charles, M.A.; Hankard, R.; Forhan, A.; Bonet, M.; Saurel-Cubizolles, M.-J.J.; Heude, B.; De Lauzon-Guillain, B. Infant feeding patterns over the first year of life: Influence of family characteristics. Eur. J. Clin. Nutr. 2013, 67, 631-637. [CrossRef] [PubMed]

82. Fein, S.B.; Labiner-Wolfe, J.; Scanlon, K.S.; Grummer-Strawn, L.M. Selected complementary feeding practices and their association with maternal education. Pediatrics 2008, 122, S91-S97. [CrossRef] [PubMed]

83. Matvienko-Sikar, K.; Kelly, C.; Sinnott, C.; McSharry, J.; Houghton, C.; Heary, C.; Toomey, E.; Byrne, M.; Kearney, P.M. Parental experiences and perceptions of infant complementary feeding: A qualitative evidence synthesis. Obes. Rev. 2018, 19, 501-517. [CrossRef] [PubMed]

84. Khandpur, N.; Blaine, R.E.; Fisher, J.O.; Davison, K.K. Fathers' child feeding practices: A review of the evidence. Appetite 2014, 78, 110-121. [CrossRef] [PubMed]

85. Litchford, A.; Roskos, M.R.S.; Wengreen, H. Influence of fathers on the feeding practices and behaviors of children: A systematic review. Appetite 2020, 147, 104558. [CrossRef]

86. Köksal, E.; Yalçın, S.S.; Pekcan, G.; Özbaş, S.; Tezel, B.; Köse, M.R. Complementary feeding practices of children aged 12-23 Months in Turkey. Cent. Eur. J. Public Health 2015, 23, 149-154. [CrossRef]

87. Maier, A.; Chabanet, C.; Schaal, B.; Leathwood, P.; Issanchou, S. Food-related sensory experience from birth through weaning: Contrasted patterns in two nearby Europeans regions. Appetite 2007, 49, 429-440. [CrossRef]

88. European Food Safety Authority (EFSA). Scientific Opinion on nutrient requirements and dietary intakes of infants and young children in the European Union. EFSA J. 2013, 11, 1-103. [CrossRef]

89. Lennox, A.; Sommerville, J.; Ong, K.; Henderson, H.; Allen, R. Diet and Nutrition Survey of Infants and Young Children, 2011; Department of Health and Food Standards Agency: London, UK, 2013.

90. Patro-Gołąb, B.; Zalewski, B.M.; Kołodziej, M.; Kouwenhoven, S.; Poston, L.; Godfrey, K.M.; Koletzko, B.; Van Goudoever, J.B.; Szajewska, H. Nutritional interventions or exposures in infants and children aged up to 3 years and their effects on subsequent risk of overweight, obesity and body fat: A systematic review of systematic reviews. Obes. Rev. 2016, 17, 1245-1257. [CrossRef] [PubMed]

91. Mennella, J.A. Ontogeny of taste preferences: Basic biology and implications for health. Am. J. Clin. Nutr. 2014, 99, 704-711. [CrossRef]

92. Burdette, H.L.; Whitaker, R.C.; Hall, W.C.; Daniels, S.R. Maternal infant-feeding style and children's adiposity at 5 years of age. Arch. Pediatr. Adolesc. Med. 2006, 160, 513-520. [CrossRef]

93. Brown, A.; Lee, M. Maternal child-feeding style during the weaning period: Association with infant weight and maternal eating style. Eat. Behav. 2011, 12, 108-111. [CrossRef]

94. Gross, R.S.; Mendelsohn, A.L.; Fierman, A.H.; Messito, M.J. Maternal controlling feeding styles during early infancy. Clin. Pediatr. 2011, 50, 1125-1133. [CrossRef]

95. Holub, S.C.; Dolan, E.A. Mothers' beliefs about infant size: Associations with attitudes and infant feeding practices. J. Appl. Dev. Psychol. 2012, 33, 158-164. [CrossRef]

96. De Souza Rezende, P.; de Moraes, D.E.B.; Mais, L.A.; Warkentin, S.; Taddei, J.A.D.A.C. Maternal pressure to eat: Associations with maternal and child characteristics among 2-to 8-year-olds in Brazil. Appetite 2019, 133, 40-46. [CrossRef]

97. Farrow, C.; Blissett, J. Does maternal control during feeding moderate early infant weight gain? Pediatrics 2006, 118, e293-e298. [CrossRef]

98. Galloway, A.T.; Fiorito, L.M.; Francis, L.A.; Birch, L.L. "Finish your soup": Counterproductive effects of pressuring children to eat on intake and affect. Appetite 2006, 46, 318-323. [CrossRef]

99. Fildes, A.; van Jaarsveld, C.H.M.; Llewellyn, C.; Wardle, J.; Fisher, A. Parental control over feeding in infancy. Influence of infant weight, appetite and feeding method. Appetite 2015, 91, 101-106. [CrossRef] [PubMed]

100. Ministerio de Sanidad de España: Porcentaje de Personas con Obesidad, por Sexo Según Comunidad Autónoma. Available online: https:/ / www.mscbs.gob.es/estadEstudios/sanidadDatos/tablas/tabla10.htm (accessed on 20 December 2020).

101. McPhie, S.; Skouteris, H.; Fuller-Tyszkiewicz, M.; McCabe, M.; Ricciardelli, L.A.; Milgrom, J.; Baur, L.A.; Dell'Aquila, D. Maternal predictors of preschool child-eating behaviours, food intake and body mass index: A prospective study. Early Child Dev. Care 2012, 182, 999-1014. [CrossRef]

102. Blissett, J.; Meyer, C.; Haycraft, E. Maternal and paternal controlling feeding practices with male and female children. Appetite 2006, 47, 212-219. [CrossRef] [PubMed]

103. Lee, H.; Keller, K.L. Children who are pressured to eat at home consume fewer high-fat foods in laboratory test meals. J. Acad. Nutr. Diet. 2012, 112, 271-275. [CrossRef]

104. Webber, L.; Cooke, L.; Hill, C.; Wardle, J. Child adiposity and maternal feeding practices: A longitudinal analysis. Am. J. Clin. Nutr. 2010, 92, 1423-1428. [CrossRef]

105. Brown, A.; Lee, M. Breastfeeding is associated with a maternal feeding style low in control from birth. PLoS ONE 2013, 8, 1-7. [CrossRef] [PubMed] 
106. Synnott, K.; Bogue, J.; Edwards, C.A.; Scott, J.A.; Higgins, S.; Norin, E.; Frias, D.; Amarri, S.; Adam, R. Parental perceptions of feeding practices in five European countries: An exploratory study. Eur. J. Clin. Nutr. 2007, 61, 946-956. [CrossRef] [PubMed]

107. Duke, R.E.; Bryson, S.; Hammer, L.D.; Agras, W.S. The relationship between parental factors at infancy and parent-reported control over children's eating at age 7. Appetite 2004, 43, 247-252. [CrossRef] [PubMed]

108. Li, R.; Scanlon, K.S.; May, A.; Rose, C.; Birch, L. Bottle-feeding practices during early infancy and eating behaviors at 6 years of age. Pediatrics 2014, 134, S70-S77. [CrossRef]

109. Timby, N.; Hernell, O.; Lönnerdal, B.; Domellöf, M. Parental feeding control in relation to feeding mode and growth pattern during early infancy. Acta Paediatr. 2014, 103, 1072-1077. [CrossRef] [PubMed]

110. Warkentin, S.; Mais, L.A.; De Oliveira, M.D.R.D.; Carnell, S.; de Aguiar CarrazedoTaddei, J.A. Relationships between parent feeding behaviors and parent and child characteristics in Brazilian preschoolers: A cross-sectional study. BMC Public Health 2018, 18, 1-11. [CrossRef]

111. Dinkevich, E.; Leid, L.; Pryor, K.; Wei, Y.; Huberman, H.; Carnell, S. Mothers' feeding behaviors in infancy: Do they predict child weight trajectories? Obesity 2015, 23, 2470-2476. [CrossRef]

112. Gonçalves, S.; Lima, V.; Machado, B.C.; Machado, P. Maternal-child feeding practices and associations with maternal and child characteristics. Nutr. Today 2017, 52, 232-239. [CrossRef]

113. Gross, R.S.; Fierman, A.H.; Mendelsohn, A.L.; Chiasson, M.A.; Rosenberg, T.J.; Scheinmann, R.; Messito, M.J. Maternal perceptions of infant hunger, satiety, and pressuring feeding styles in an urban Latina WIC population. Acad. Pediatr. 2010, 10, 29-35. [CrossRef]

114. Loth, K.A.; MacLehose, R.F.; Fulkerson, J.A.; Crow, S.; Neumark-Sztainer, D. Eat this, not that! Parental demographic correlates of food-related parenting practices. Appetite 2013, 60, 140-147. [CrossRef] [PubMed]

115. Real, H.; Oliveira, A.; Severo, M.; Moreira, P.; Lopes, C. Combination and adaptation of two tools to assess parental feeding practices in pre-school children. Eat. Behav. 2014, 15, 383-387. [CrossRef]

116. Russell, C.G.; Haszard, J.J.; Taylor, R.W.; Heath, A.L.M.; Taylor, B.; Campbell, K.J. Parental feeding practices associated with children's eating and weight: What are parents of toddlers and preschool children doing? Appetite 2018, 128, 120-128. [CrossRef] [PubMed]

117. Hughes, S.O.; Frankel, L.A.; Beltran, A.; Hodges, E.; Hoerr, S.; Lumeng, J.; Tovar, A.; Kremers, S. Food parenting measurement issues: Working group consensus report. Child. Obes. 2013, 9, S95-S102. [CrossRef]

118. Stifter, C.A.; Moding, K.J. Understanding and measuring parent use of food to soothe infant and toddler distress: A longitudinal study from 6 to 18 months of age. Appetite 2015, 95, 188-196. [CrossRef] [PubMed] 